\title{
Zagłada Żydów na polskich terenach wcielonych do Rzeszy, red. Aleksandra Namysło, Instytut Pamięci Narodowej, Warszawa 2008
}

Zagłada Żydów na polskich terenach wcielonych do Rzeszy pod redakcją Aleksandry Namysło ukazała się cztery lata po tomie Akcja Reinhardt. Zagłada Żydów w Generalnym Gubernatorstwie pod redakcją Dariusza Libionki. Oba wydawnictwa stanowią pokłosie międzynarodowych konferencji naukowych organizowanych przez Instytut Pamięci Narodowej i Niemiecki Instytut Historyczny i składają się na całościowy obraz zagłady Żydów na ziemiach polskich.

Recenzowany tom zawiera teksty części referatów - żałować należy, że nie wszystkich - wygłoszonych na międzynarodowej konferencji „Zagłada ludności żydowskiej na polskich terenach wcielonych do Rzeszy w czasie II wojny światowej”, która odbyła się w dniach od 15 do 17 września 2005 r. w Katowicach. Przepis na tego typu konferencje jest sprawdzony i stosunkowo prosty: organizatorzy zapraszają historyków z Niemiec, Izraela, czasami z krajów Europy Wschodniej oraz Stanów Zjednoczonych i Polski, co daje możliwość zapoznania się z badaniami często najwybitniejszych specjalistów. Podejście takie ma jednak swoje wady, sprowadzające się do łatwego do przewidzenia sprofilowania problematyki będącej przedmiotem sesji. Upraszczając nieco, najczęściej o sprawcach mówią niemal wyłącznie historycy niemieccy, o ofiarach - izraelscy, świadkami zaś zajmują się badacze polscy. Jest to również widoczne w dyskusjach, w czasie których historycy niemieccy rzadko wypowiadają się na temat postaw ludności ziem okupowanych wobec Zagłady, a z kolei polscy badacze historię sprawców pozostawiają niemieckim kolegom, którzy dyskutują między sobą o nurtujących ich od lat problemach. Takie też wrażenie wyniosłem z konferencji w Katowicach. Nawet w tych przypadkach, gdy organizatorzy świadomie dążą do przełamania tego schematu, efekty nie zawsze odpowiadają oczekiwaniom.

W omawianym tomie o sprawcach piszą nie tylko autorzy niemieccy (Jochen Böhler, Michael Alberti, Klaus-Michael Mallmann, Karin Orth, Joachim Riedel), ale również polscy: Jacek Andrzej Młynarczyk, Ryszard Kaczmarek i Jan Grabowski (choć nawiasem mówiąc, dwie z tych osób związane są z instytucjami zagranicznymi bądź de facto, jak w przypadku Młynarczyka, reprezentują historiografię niemiecką). Drugą grupę autorów zajmujących się tym tematem stanowią badacze z ośrodków naukowych związanych z miejscami pamięci lub muzeami funkcjonującymi na terenie byłych nazistowskich obozów (Anna Ziółkowska, Danuta Drywa, Wacław Długoborski), co też jest wyrazem pewnej tendencji, o której niżej. Na postawach i reakcjach ofiar albo świadków skupiają się głównie historycy polscy (Julian Baranowski, Aleksandra Namysło, Dorota Siepracka, Dariusz Libionka) i z Izraela (Sara Bender, Dan Michman). 
Sformułowane wcześniej uwagi mają jedynie wskazać, że istnieje problem może nie tyle rozmijania się poszczególnych historiografii narodowych, ile ich niezależnego funkcjonowania obok siebie. Pozostaje tylko - a może aż - kwestia odpowiedniego doboru autorów, by publikacja materiałów z sesji stała się - żeby posłużyć się słowami Aleksandry Namysło - „swoistym kompendium, w którym zebrano najnowsze ustalenia badawcze” i „znaczącym uzupełnieniem stanu wiedzy na temat Holokaustu na ziemiach polskich”. Nie ulega wątpliwości, że zarówno w odniesieniu do okresu gettoizacji, procesu decyzyjnego dotyczącego Zagłady, przebiegu eksterminacji, jak i zjawisk jej towarzyszących na polskich ziemiach wcielonych do Rzeszy (reakcja ofiar i świadków, rozliczenia) cel ten został osiągnięty.

Tom składa się z pięciu części dotyczących odpowiednio: roli ziem wcielonych do Rzeszy w historii zagłady Żydów, etapów działań antyżydowskich w latach 19391943, obozów koncentracyjnych i obozów zagłady, postaw ofiar wobec eksterminacji, a wreszcie reakcji Polski i wolnego świata. W części pierwszej (Rola i miejsce terenów wcielonych do Rzeszy w procesie decyzyjnym Zagłady) zamieszczono teksty Jacka Andrzeja Młynarczyka i Ryszarda Kaczmarka. Poprzez zastosowanie metody porównawczej obaj autorzy wykazują, że przypadek ziem wcielonych potwierdza znaną tezę, iż zarówno proces decyzyjny, jak i przebieg Zagłady były wynikiem splotu inicjatyw oddolnych, aktywności nazistów i różnego stopnia natężenia polityki antyżydowskiej na poszczególnych terenach okupowanych, a także polityki berlińskiej centrali. Na tle wszystkich ziem wcielonych do Rzeszy (również zachodnich i południowych obszarów Europy) dużą aktywnością w radykalizacji polityki antyżydowskiej wykazywał się namiestnik Kraju Warty Arthur Greiser (Kaczmarek). Jego inicjatywa wymordowania „swoich” „nieproduktywnych” Żydów i podobna inicjatywa Odilo Globocnika, szefa SS i policji w dystrykcie lubelskim GG, pokazuje, że obaj stali się „prekursorami Zagłady na terenach okupowanej Polski” (Młynarczyk). W tym kontekście szkoda, że w tomie nie znalazł się tekst referatu wygłoszonego podczas katowickiej konferencji przez Petera Kleina o ekonomicznych aspektach funkcjonowania obozów zagłady w Kraju Warty. Fakt, że Zagłada w Kraju Warty była finansowana z budżetu zarządzanego przez Greisera, pokazuje, że w przeciwieństwie do Lubelszczyzny (i całej GG), decydujący wpływ na genezę i przebieg eksterminacji Żydów miały cywilne struktury władzy okupacyjnej. O polityce antyżydowskiej, procesie decyzyjnym i roli przywódców nazistowskich wspominają też autorzy tekstów odnoszących się do losów ludności żydowskiej w kolejnych etapach wojny i szeroko pojętego procesu Zagłady na poszczególnych polskich terenach wcielonych do Rzeszy (część Od wyalienowania do Zagłady). Ten blok tekstów otwiera artykuł Jochena Böhlera z NIH, który konsekwentnie przybliża polskiemu czytelnikowi zbrodnie dokonywane przez Wehrmacht i Einsatzgruppen w Polsce podczas trwania zarządu wojskowego (1 IX 25 X 1939 r.) Po przeglądzie przykładów z późniejszych ziem wcielonych i innych ziem polskich, autor podkreśla rolę, jaką w kolejnych latach odegrało zarówno przyzwolenie Wehrmachtu na „,spontaniczne« antysemickie wystapienia i morderstwa”, jak i jego aktywny w nich udział, a także masakry oraz „rozwiązania” podejmowane przez grupy operacyjne. Jan Grabowski z Uniwersytetu Ottawskiego, koncentrując 
się na losie ludności żydowskiej rejencji ciechanowskiej, wyraźnie podkreśla, że „pomimo wielu podobieństw, polityka władz niemieckich wobec Żydów mieszkających w rejencji różniła się od tej prowadzonej na innych obszarach wcielonych do Rzeszy”. Decydowała o tym większa liczba Żydów i możliwość ich kontaktów z mieszkańcami warszawskiego getta. Z kolei Michael Alberti, opisując „ostateczne rozwiązanie kwestii żydowskiej w Kraju Warty”, wskazuje, że w sytuacjach budzących wątpliwości i w sporach pomiędzy SS, policją i administracją cywilną „ostateczna decyzja należała do Greisera”. Dokładniej też opisuje sam proces decyzyjny prowadzący do Zagłady w Kraju Warty, zdecydowanie podkreślając, że to Greiser był tym, który podjął decyzję o masowej zagładzie Żydów. Jego rola nie zmniejszyła się nawet po czasowym zakończeniu deportacji we wrześniu 1942 r., kiedy to nie pozwolił na przejęcie getta łódzkiego przez Himmlera i Globocnika. Także ostateczna likwidacja getta dokonała się wskutek działań Greisera i Himmlera, którzy nie zważali na sprzeciw ministra zbrojeń Speera, chcącego wykorzystać ludność żydowską jako siłę roboczą. Rolę Greisera wyraźnie też podkreśla Klaus-Michael Mallmann, choć w głównej mierze skupia się na podmiotach odpowiedzialnych za logistyczne przygotowanie Szoa w Kraju Warty - przede wszystkim Policji Bezpieczeństwa w Łodzi (w nawiązaniu do struktur i osób zajmujących się „bezpieczeństwem” Rzeszy w Berlinie oraz innych miastach Kraju Warty). Rzecz jasna, wspomniani autorzy nie skupiają się wyłącznie na procesie decyzyjnym - głównym ich zamierzeniem było ukazanie przebiegu i kontekstu eksterminacji na poszczególnych ziemiach wcielonych. Trudno jednak uciec od wrażenia, że większość artykułów pokazuje zjawisko gettoizacji i Zagładę „z perspektywy sprawcy”, co oczywiście nie stanowi zarzutu, a jest nawet interesujące z poznawczego punktu widzenia. Można żałować, że w tej części tomu skoncentrowano się na przedstawieniu sytuacji w Kraju Warty, a zabrakło tekstów dotyczących Zagłady na wcielonych do Rzeszy obszarach na północny i południu Polski. Teksty na temat losu Żydów z tych ziem pojawią się później, przy opisie zagłady Żydów w obozach w Stutthofie i Auschwitz-Birkenau.

Kolejne trzy artykuły polskich historyków - Anny Ziółkowskiej (o obozach pracy przymusowej dla Żydów w Kraju Warty), Danuty Drywy (o Żydach w obozie w Stutthofie), Wacława Długoborskiego (o Żydach z polskich ziem wcielonych w obozie Auschwitz-Birkenau) - wpisują się w bogatą polską „literaturę obozową”. Całe piśmiennictwo dotyczące Zagłady nie jest lekturą łatwą, ale „literatura obozowa”, czego przykładem są zamieszczone w tomie teksty, jest szczególnie przejmująca ze względu na stężenie opisywanego okrucieństwa i cierpienia. Można postawić jedynie pytanie, czy postawy Polaków przedstawione przez Annę Ziółkowską były tak jednoznacznie pozytywne, mając na względzie chociażby obserwowany przez polskie podziemie na przełomie 1941 i 1942 r. wzrost antysemityzmu wśród Polaków na ziemiach wcielonych. Ostatni tekst wchodzący w skład części poświęconej obozom, autorstwa niemieckiej historyk Karin Orth, stanowi interesujący przyczynek do biografii komendanta Auschwitz Rudolfa Hößa.

Autor artykułu otwierającego czwartą część publikacji (Postawy i zachowania wobec Zagłady), Dan Michman, odwołując się do najnowszych badań, stara się re- 
definiować znaczenie terminów: „Judenraty”, „getta”, „,ostateczne rozwiązanie kwestii żydowskiej”. Jednak, jak się wydaje, nie chodzi tutaj o postawy samych Żydów (także członków Judenratów), lecz o sposób wykorzystywania tych instytucji na drodze do „ostatecznego rozwiązania kwestii żydowskiej”. Dyskusja o strategiach Żydów wobec nazistowskiej polityki i funkcjonowania powołanych przez nich do życia instytucji nie mogła obyć się bez przywołania postaci Chaima Mordechaja Rumkowskiego (tekst Juliana Baranowskiego) i Mojżesza Merina, przełożonego Centrali Żydowskich Rad Starszych Wschodniego Górnego Śląska (studium Aleksandry Namysło, najlepszej znawczyni tematu). Sara Bender, poprzez porównanie walki Żydów w Warszawie, Wilnie i Białymstoku, kwestionuje zasadność stosowania wobec tej ostatniej terminu „powstanie”.

Najbardziej interesująca, z punktu widzenia moich własnych badań, jest ostatnia część tomu (Reakcje i rozliczenia). Tekst Doroty Sieprackiej - o postawach Polaków wobec ludności żydowskiej w Kraju Warty - nawiązuje do jej tekstu z tomu Polacy iŻydzi pod okupacją niemiecka 1939-1945 wydanego w 2006 r. pod red. Andrzeja Żbikowskiego. Uwypukla ona pozytywny aspekt tej sprawy. Podejście takie kontrastuje z obrazem postaw ludności polskiej wyłaniającym się z tekstu o reakcjach Polskiego Państwa Podziemnego autorstwa Dariusza Libionki, zwłaszcza w części powstałej w oparciu o dokumentację polskiego podziemia. Autor wprowadził do obiegu wiele ustaleń i zaproponował nowe interpretacje odnośnie do „polityki informacyjnej [Polskiego Państwa Podziemnego] na temat zbrodni niemieckich wobec Żydów na polskich ziemiach wcielonych do Rzeszy”. Nie ustrzegł się jednak pewnych nieścisłości i nadinterpretacji (skorygowałem je w wydanej niedawno książce o pierwszych reakcjach polskiego Londynu i podziemia na deportacje Żydów do obozów zagłady). Wydaje się natomiast, że skądinąd bardzo interesujący tekst Gerharda L. Weinberga - o reakcji aliantów na wiadomości dotyczące ostatecznego rozwiązania kwestii żydowskiej na Wschodzie - powinien być jedynie wstępem do podobnych rozważań na temat zbrodni wobec Żydów na ziemiach wcielonych, a później w obozie Auschwitz. Dobrym podsumowaniem tomu jest artykuł Joachima Riedla z Zentrale Stelle der Landesjustizverwaltungen zur Aufklärung nationalsozialistischer Verbrechen [Urząd Centralny Krajowych Zarządów Sprawiedliwości dla Wyjaśnienia Zbrodni Narodowosocjalistycznych] w Ludwigsburgu o postępowaniach karnych w Niemczech (zarówno w RFN, jak i NRD) w procesach o eksterminację Żydów na ziemiach wcielonych do Rzeszy. Niestety, w tomie zabrakło wygłoszonego na konferencji referatu na temat działań polskiego wymiaru sprawiedliwości.

Recenzowane wydawnictwo IPN o zagładzie Żydów na polskich terenach wcielonych do Rzeszy powinno się znaleźć w biblioteczce każdej osoby interesującej się tematyką Szoa - zresztą obok innych, wspomnianych tomów IPN, redagowanych przez Dariusza Libionkę i Andrzeja Żbikowskiego. Należałoby sobie życzyć, by w niedalekiej przyszłości pojawił się kolejny tom z tej serii - poświęcony Kresom Wschodnim. 